\title{
SPEP: High-Resolution Stalagmite Records of NE Atlantic Climate in the Last Millennium
}

High-resolution climate records are one focus of the PAGES PEP III programme, and the speleothem project (SPEP) focuses on using cave dripstones as archives (Lauritzen 1998). Recently, two stalagmite records from the NE Atlantic region have been published. The records cover the last millennium and provide calibrated paleoclimate proxies. One, from Rana, Norway, is a paleotemperature record derived from calibrated ${ }^{18} \mathrm{O}$ isotopes (Lauritzen and Lundberg, 1999). The second, is a paleoprecipitation record from calibrated annual growth rate variations from a stalagmite from NW Scotland. Both records are shown for the last millennium in Figure 1.

The paleotemperature record for stalagmite SG-93 from Rana, Norway, is derived from the speleothem delta function (SDF), which is a transfer function between the ${ }^{18} \mathrm{O}$ signal of speleothem calcite and surface ground temperature. The function is based on physical principles, relating ${ }^{18} \mathrm{O}$ of the calcite to thermodynamic fractionation, and to the dripwater function, which in turn relates ${ }^{18} \mathrm{O}$ of dripwaters to that of local precipitation. The SDF is calibrated for this site against 5 datapoints of known temperaature and precise age. The stalagmite itself is dated by 12 TIMS U-Th analyses over its complete deposition period (the Holocene), with two analyses covering the last millennium.

The paleoprecipitation record for stalagmite SU-96-7 from Assynt, NW Scotland, is derived from annual growth rate variability. Luminescent organic matter in stalagmites may form annual bands, allowing growth rate to be precisely determined. Stalagmite growth rate is often controlled by precipitation (Brook et al., 1999; Tan et al., 1999), so annual bands can be used to derive long precipitation records. An 1100-year high-resolution record of precipitation was reconstructed after calibration against instrumental rainfall and temperature records. Periods of high growth rate correlate with low rainfall, which decreases the saturation of the overlying histosol and results in increased soil $\mathrm{CO}_{2}$ production. The location of the cave, immediately to the west of 1000-m high mountains, implies that the precipitation is predominantly orographic and closely linked to the North Atlantic Oscillation.

Comparison of the two records is presented in Figure 1. It is apparent that there is a reasonable correlation between the two sites. This may be explained by a common linkage with NAO strength. The Scottish site is strongly dependent on the NAO: growth rate is highest when the NAO is negative, and mean annual precipitation is low. Under these conditions, semipermanent high-pressure systems are established over Iceland, and $\mathrm{N}$ Norway experiences cold, N and NW arctic air mass. When the growth rate is low in NW Scotland, the NAO is positive and mean annual rainfall increases. Under these conditions $S$ and SW circulation is also established over Rana and the temperature increases.

Our comparison of data from the NW Atlantic region has interesting implications for the understanding of climate change. For the Norwegian temperature record, rapid changes of 1-2 degrees (mean annual temperature) over less than 100 years are not uncommon. For the Scottish high-resolution record, we note that changes in precipitation over the historical period are as large as those that have occurred over the last 1000 years, but are not particularly unusual. Also, we note a dominant spectral frequency of 82 and 6-7 years, the latter reflecting NAO dominance at the site, and the former may be related to solar variability or ocean-atmosphere interactions.

\section{References}

Brook, G.A. et al., 1999. The Holocene, 9, 695-706. Lauritzen, S.E. 1998. In Gasse, F. et al. (Eds.),

1999: PEP III: The Pole-Equator-Pole transect through Europe and Africa, pp. 37-43. PAGES Workshop Report 97-2.

Lauritzen \& Lundberg, 1999. The Holocene, 9 659-670.

Proctor, C.J. et al., 2000. Climate Dynamics, in press. Qin, X. et al., 1999. The Holocene, 9, 689-694.
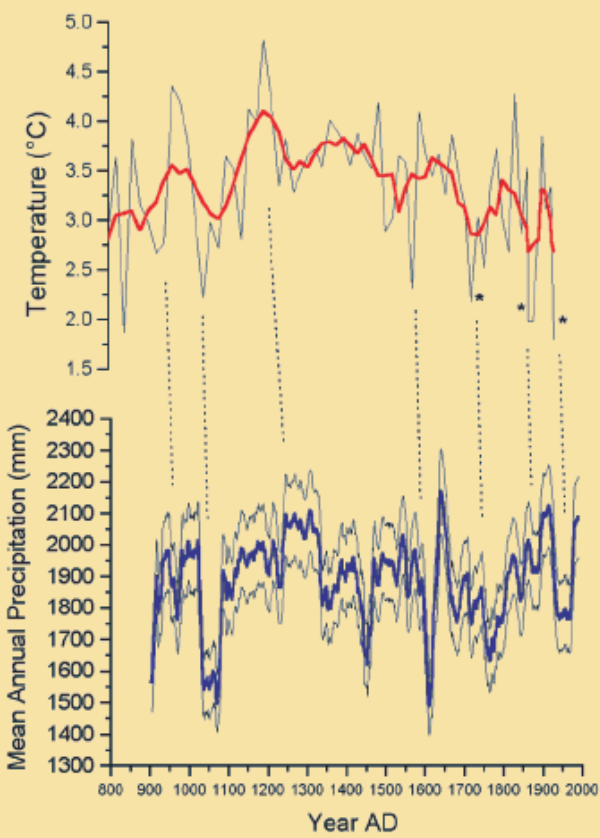

Figure 1

Top: Mean annual temperature reconstructed from the SDF of stalagmite SG-93, Rana, northern Norway. The timing of the three coldest decades over the historical period are shown by asterisks.

Bottom: Reconstructed mean annual rainfall for NW Scotland from annual growth rate variability. Rainfall is derived from a 114 year historical calibration against instrumental temperature and precipitation ( $r=0.80$, decadal average), and extrapolated over the last 1100 years. Error bars are $\pm 2 \mathrm{~s}$ derived from an assumed maximum $\pm 0.43^{\circ} \mathrm{C}$ temperature variability over the time period. Tie lines suggest correlations between periods of low temperature in N Norway and low rainfall in NW Scotland.

\section{Andy Baker and Chris Proctor}

Department of Geography, University of Newcastleupon-Tyne, UK

andy.baker@ncl.ac.uk

\section{Stein-Erik Lauritzen}

Department of Geology, University of Bergen, Norway stein.lauritzen@geol vib no

\section{JOYCE LUNDBERG}

Department of Geography, Carleton University, Ottawa, Canada 